\title{
一解説 連裁(1)-
}

\section{射出成形における可視化実験解析法}

東京大学国際・産学共同研究センター

横井 秀俊

\section{1.はじめに}

射出成形はプラスチック成形加工の代表的な成 形技術で,自動車のバンパー等の大物成形部品か ら各種ハウジング類,ギヤ、レンズ,CDやDVD等の精 密成形品まで,およそ形を持ったプラスチック部品は この射出成形によりつくられる. その工程は,米粒状 に調整された成形材料 (ペレット)を(1)加熱シリンダ 内で溶かす,(2)金型に注入する,(3)金型内で冷却し て形状を転写・凍結する,と極めて単純である. 一般 に,1サイクルわずか数秒から数10秒の工程間に,圧 縮性と断熱特性に富む成形材料は，常温・常圧から $200 \sim 300^{\circ} \mathrm{C} \cdot$ 数 100 気圧以上の高温・高圧環境を経 て常温・常圧に復帰する. やや専門的だが,非ニュ 一トン流体,結晶化過程と体積収縮,分子/瀻維配 向と異方性発現などの諸因子が重睤し,その工程に は見かけによらず実に複雑な成形現象が展開され ている.しかしながら,こうした成形工程は厚い鋼鉄 製の加熱シリンダ・金型内に閉ざされ,センサー設置 箇所での数点の圧力・温度計測情報を除いて,外か ら容易には窥い知ることができないブラックボックス となっていた.

射出成形工程には,大別して加熱シリンダと金型 の2つのブラックボックスがある. 圧力および温度の インプロセス計測情報を重轠させながら材料挙動・ 状態変化を直接観察できれば,これらブラックボック ス内深くに光を導き入れ，成形現象の解明に飛躍的 な進歩をもたらすことが可能となる.ここに可視化技 術への大きな期待が込められている.

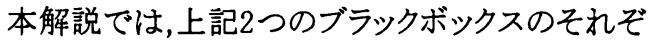
れについて取り上げ,2回に分けて可視化実験解析 法の解説を連載する. 第1回となる本稿では,射出成 形金型内の可視化技術を取り上げ,その発展の歴 史と,著者らの最新の研究成果事例について,以下 に順を追って紹介する.

\section{2. 金型内可視化技術の分類亡発展の歴史}

金型内可視化技術は,高速ビデオ等を用い動的 画像を記録する動的可視化法と,材料にマーキング などの事前処理を加え成形後のサンプルを観察す

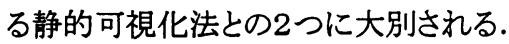

\section{1 䦽的可視化法}

各種動的可視化法の分類を図 1 に示す ${ }^{1)}$. キャビ ティ充填パターンのようなフローフロント形状の時間 変化観察では,光反射方式が適用される.一方,䋐 維配向挙動など流動樹脂内部の情報が必要な場 合には，樹脂内の透過光を観察する必要があり,バッ クライト法による光透過方式,レーザライトシート法に よる光切断方式の2方式が用いられる.

\section{(1)光透過方式}

動的可視化の研究は,1950年のR.S.Spencerと G.D.GilmoreによるPhoto Moldの開発に始まる.こ の金型は,対向平行ガラス厚板の裏側に鏡を $45^{\circ}$ 配 置・固定した一眼レフカメラのような構造で, 実成形 機上で64frames/sの高速にて型内現象の撮影に成 功した ${ }^{2), 3)}$.この研究は余りにも先駆的で,スキン層・コ ア層,補償流れなど成形現象の基本となる概念は当 時すでに彼らによって提示されている. その後 1970 年代に入り,平行ガラス板の金型をキャピラリーレオ メータ等と組合わせ行ったジェッティング現象の解 析をはじめ,サンドイッチ成形過程の観察 ${ }^{4)-6)}$,発泡成 形における気泡の成長過程の動的可視化 ${ }^{7,8)}$ が行わ れた.

光透過方式の金型に偏向板, 1/4波長板を対向 して二組設置し,光弾性実験系を構成する.これに より,樹脂流動過程および圧縮・保圧冷却過程にお ける固化層の成長と応力 (複屈折) 分布を動的に可 視化することができる.これまで同方式によって， 1978年にキャビティ面方向からの観察"が,また1989

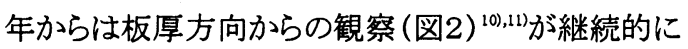


行われている. 特に後者では, 黒崎, 佐藤らが固化層 成長過程,ひけ·そり生成過程の観察に基づき生成 機構の検郡,伝熱学的手法による制御方法を提案し

ている.

\section{(2)光反射方式}

光反射方式は,光透過方式にやや遅れて登場 した. 型内流動の数值解析モデルを構成する上で,
樹脂流動パターンに加えてキャビティ内の圧力・温 度計測データが同時に求められる. そのため,(1)の 方式において片側のガラスブロックに替えて,センサ 一を装填した金属ブロックを組み入れたことに始ま $\Xi^{(2), 13)}$. 例えば,M.R.Kamalらは,半円形状キャビティ の充填・保圧冷却過程の理論検証を目的に,200 frames/sの高速度カメラによりフロント速度と圧カプ

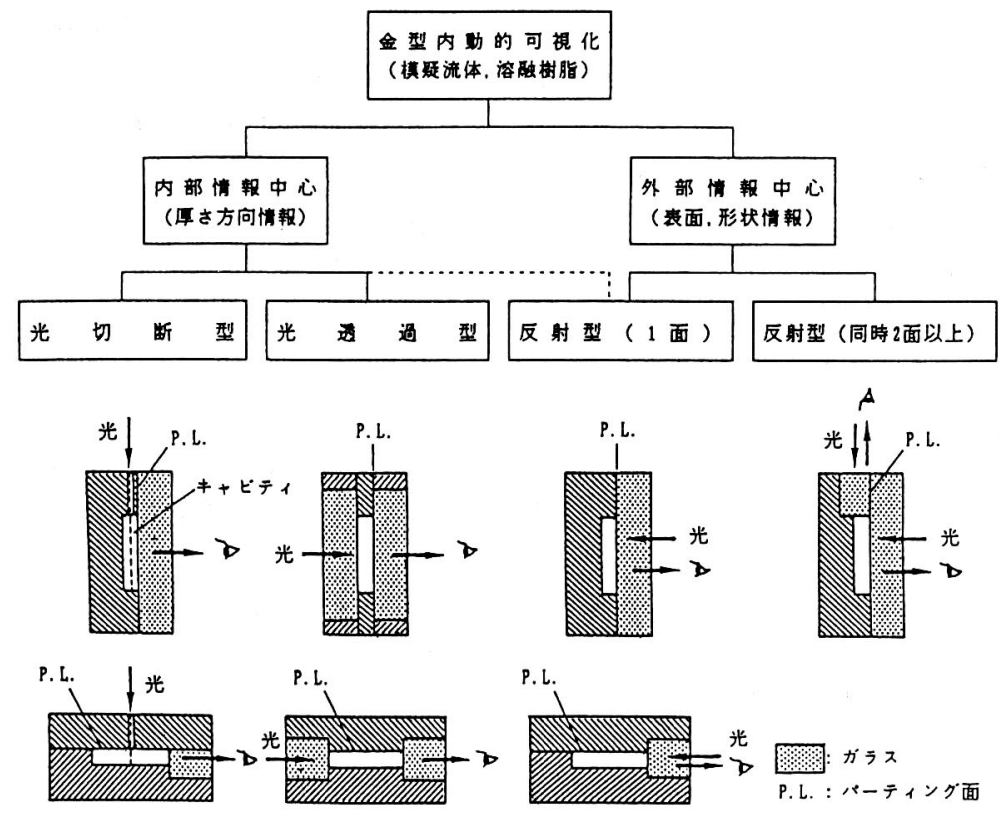

図1 射出成形金型内の各種動的可視化法

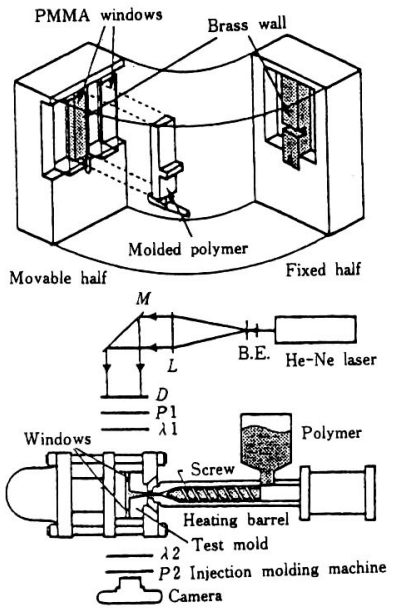

図2 複屈折分布の可視化金型 と光学系 (黒崎, 佐藤ら)

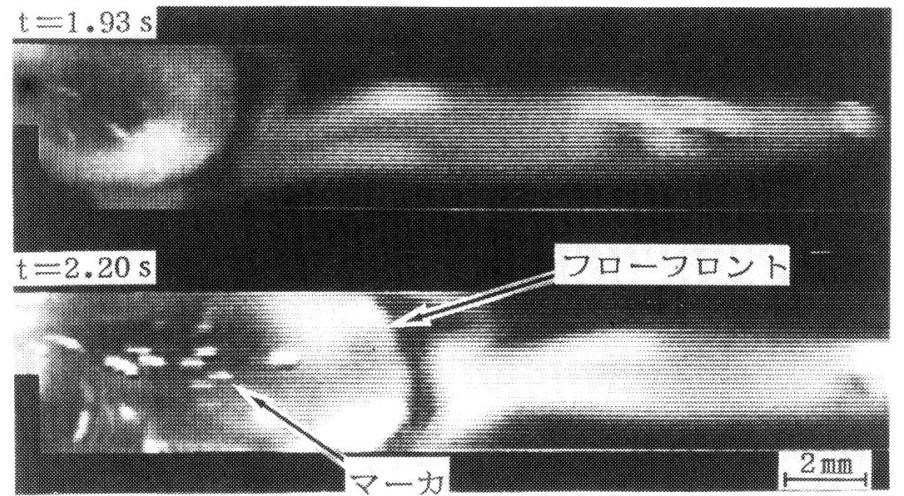

図3 レーザ可視化金型による光切断画像の例 (キャビティ厚さ：2mmか $4 \mathrm{~mm}$ ） 
ロファイルを同時計測した ${ }^{12)}$.

光反射方式による二方向同時可視化は,1970年 にドイツのアーヘン工科大学IKV(プラスチック加エ 研究所)によりはじめて本格的な研究がなされた. 矩形キャビティでの拡大流から平板流への遷移過 程,ウェルドライン生成現象の解析,キャビティ厚さ6 $\mathrm{mm}$ での3次元立体的速度分布の計測・表示等が行 なわれた

なお、近年では光反射方式(主に一方向反射方 式)の可視化金型により、ガスアシスト射出成形過程 の可視化解析が多方面で盛んに行われている ${ }^{(5), 16)}$ (3)光切断方式

流動樹脂内の一部をスリット状の強力な光で切断 し,この光切断面内のマーカ挙動を,切断面からかな り離れたキャビティ側面に設置したガラス空から観察 する.この際,光切断面と観察空との間には多くのマ 一カが介在する.それにも関わらず,光切断面内の マーカ輝度が高いため,任意の光切断面の画像の みを離れた端面部から観察できる. 同方式は,流れ
の可視化に広く用いられているレーザライトシート法 を、著者らが初めて金型に適用したものである.これ により板厚方向の樹脂挙動 (図3) と速度分布 ${ }^{17}$, 生 成ガスの挙動,繊維配向過程,ファウンテンフロー現 象の解析が進められた。

この他,等温系を仮定したモデル実験に適用が限 定されるが,疑似流体を用いた板厚方向流動現象の 可視化実験も一部試みられた. 例えば垂直平行ガ ラス板の間に層状インクを浮かべたシリコンオイル等 を充填し,ガラス板を落下させた際の液面部ファウン テンフローを観察する実験が行われている

\section{2 静的可視化法}

静的可視化法は,原則として金型側にはほとんど 手を加えない. 材料側にマーキング処理等を事前 に施し,取り出し後に成形品の中に凍結された情報 を読み出す方法である. 材料へのマーキング法によ って,図4の各種方法に分類される”. すなわち,着色 顔料を埋込んだ材料や着色板の積層材料をプラン ジャ方式で押し込む方法,2本の射出シリンダにより

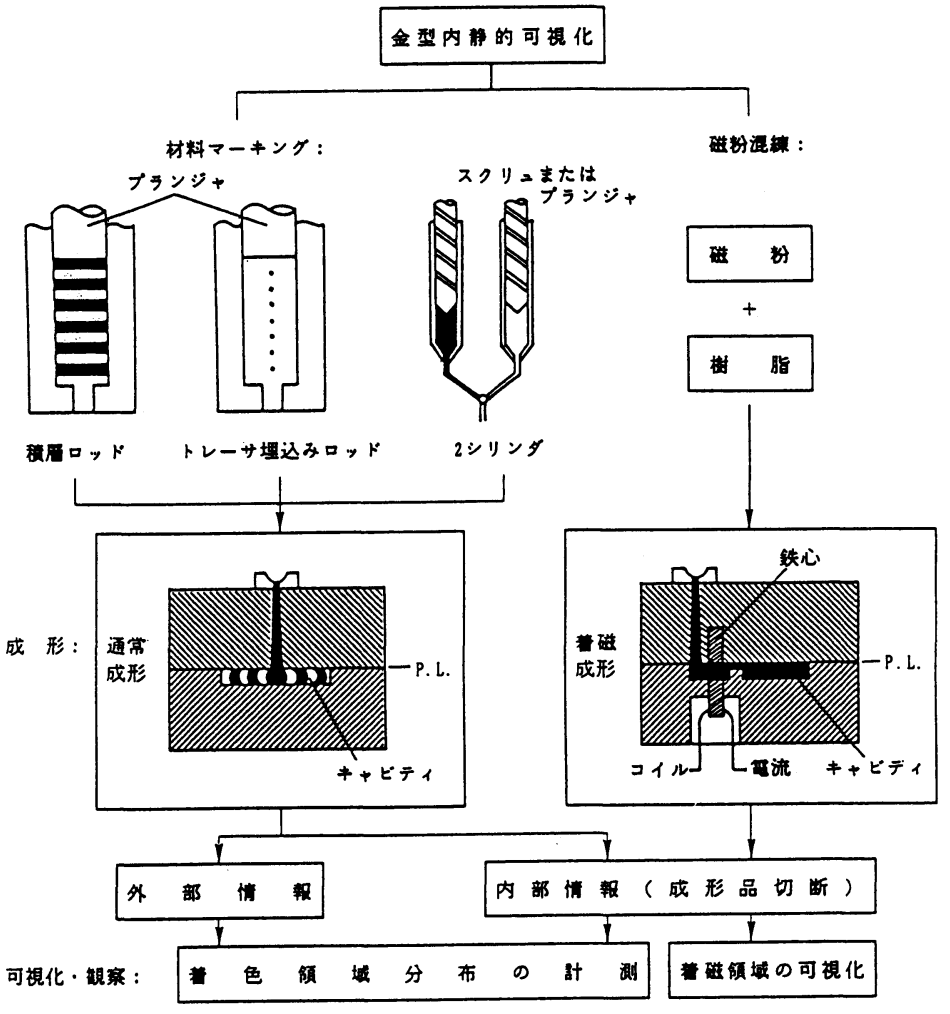

図4 射出成形金型内の各種静的可視化法 
材料を交互射出する方法,着磁によりマーキングす る方法に分類される.

\section{(1)着色材埋込み方式}

半径方向に一定間隔で小径穴明をし,同種樹脂 の着色材を埋め込んだロッド材を作製する. 同材料 をキャピラリーレオメータにより金型内に射出するこ とにより,内層部の多様な流動パターンを観察でき る ${ }^{19)}$. その後, L.R.Schmidtにより,顔料埋込み箇所を ロッド中心部のみに限定する技術的改良がはから れ,中心部の顔料部分をほとんどせん断変形させず キャビティ内へと射出させることが可能となった.こ れがSchmidtの実験で,特にスキン層近傍でのZ字状 着色パターンの生成を初めて明らかにした ${ }^{201}$.

\section{(2)着色材積層方式}

これに対し,着色板の積層ロッド材をプランジャに て金型内に押込む方法も昔から広く用いられてき た.ただしこの方法によれば,射出時に着色材料ご とに順番にゲートを通過する保証がない.このため, 定性的な理解には充分役立つものの,定量的な解 析には不向きと考えられる. 金型の可視化とは相違 するが,H.Meijerらは,1991年に着色材を多数積層充 填したシリンダ内で対向ピストンを往復動させ,生成 したファウンテンフローの流動パターン(図5)を,シミ ユレーションモデルの検証用基礎データとした ${ }^{211}$. 多 層射出成形,IC封止材の充填,ガスアシスト射出成形 などの樹脂挙動解析用基礎データの収集にも同手 法は活用されている。

\section{(3)2シリンダ方式}

2本の射出シリンダによる2色の射出樹脂を,バル ブ等の切換え機構により順次あるいは交互に金型 内に射出する方式である. シャープな樹脂の切換え 実現に課題を残すものの,簡易な可視化手法として 実際に試みられている.ただし,著者らのランナー切 替え法(次章(4)参照) 以外,報告例はほとんど見出さ れていない。

\section{(4)着磁方式}

こうした着色による材料マーキング法とは切口の 相違した手法として,著者らの開発によるゲート着磁 法がある22.. テープレコーダの原理を金型に適用し た本手法では、記録媒体として樹脂内に練り込まれ た磁粉が利用される. 樹脂がゲートを通過する際に, ゲート直前に設置された鉄心と磁気回路とにより樹 脂内の磁粉にパルス状に着磁がなされる. 着磁パタ ーンの読み出しは,サンプル切断後に,切断面の着 磁域を磁気検出液にて可視化することにより達成さ れる.

本手法は,その高い再現性とパルス着磁パターン の任意性とにより,静的可視化でありながら,動的可 視化法に準じた時間因子の導入を初めて可能とし た. 着磁パターンの現像に熟練を要する難点がある ものの,数 $10 \mu \mathrm{m}$ 高い記録解像度と併せて優れた 可視化実験解析手法として活用されている. 同手法 により,リブ,段差部等の3次元流れ,補償流れ ${ }^{23)}$ 、低 速・高速充填パターン $(\text { 図6 })^{24)}$,瀻維配向と流孔との
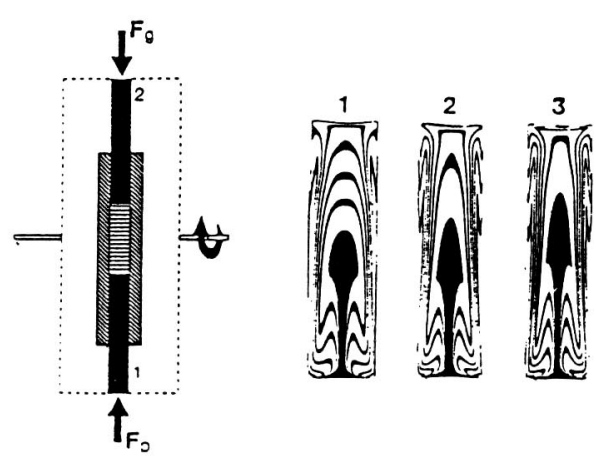

図5 着色材積層ロッド法によるファウン テンフローパターンの可視化

(H.E.H. Me i jerら )

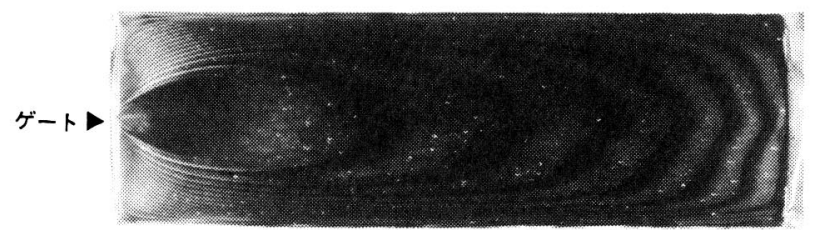

(a) 射出率 $=1.5 \mathrm{~cm}^{3} / \mathrm{s}$

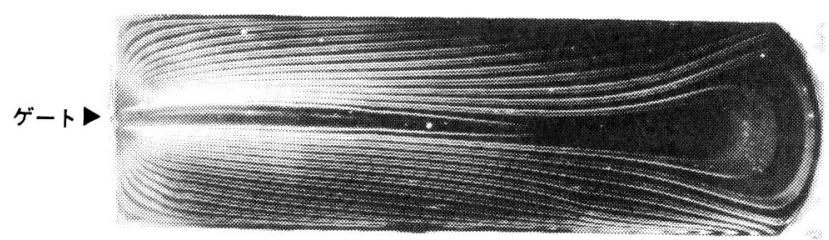

(b) 射出率 $4.0 \mathrm{~cm}^{3} / \mathrm{s}$

図6 ゲート着磁法による長尺平板キャビティ での充填挙動可視化例（板厚中心での切断） 
相関,端面部の先行流動挙動,フェノール樹脂の充 填挙動 ${ }^{25}$, 半導体封止過程 26 等の可視化解析を実施 した. 1995年にはツインゲート着磁装置を開発し,ウ エルドライン形成領域の流動パターンの観察も行っ $た^{27}$.

\section{3. 可視化観察の事例紹介}

著者らは,1986年にまず片面反射方式の可視化 金型(プリズムインサート金型)を開発した ${ }^{28)}$.これを もとに,今日まで光透過方式(バックライト金型),同時 2面反射方式(3次元可視化金型)を,さらにこれらの 流れとは独立に,すでに上述した光切断方式(レー

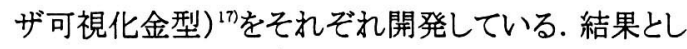
て,図1の全動的可視化法を目的に応じて使い分け ながら,これまで成形現象の解明を行ってきた. また， 静的可視化手法として,新規のゲート着磁法を開発 するとともに,動的可視化法のプリズムインサート金 型を静的可視化法の 2 シリンダ方式と組み合わせた 究極の可視化技術ーランナー切替え方式一を開発 した. 以下に,こうした各種可視化技術の解説と可視 化事例を紹介する. なお,レーザ可視化金型とゲー 卜着磁法については上述したので,そちらを参照され たい.

\section{(1)プリズムインサート金型}

プリズムインサート金型（図7)は，(1)通常の成形条 件のもとで,(2)通常の金型と同様にして,(3)通常の成 形機上で使用できることを目的として,高耐圧 (500気 圧まで)の実用的可視化金型として開発された ${ }^{28,29)}$. プリズムの素材は石英ガラスである. 図8に高速ビデ

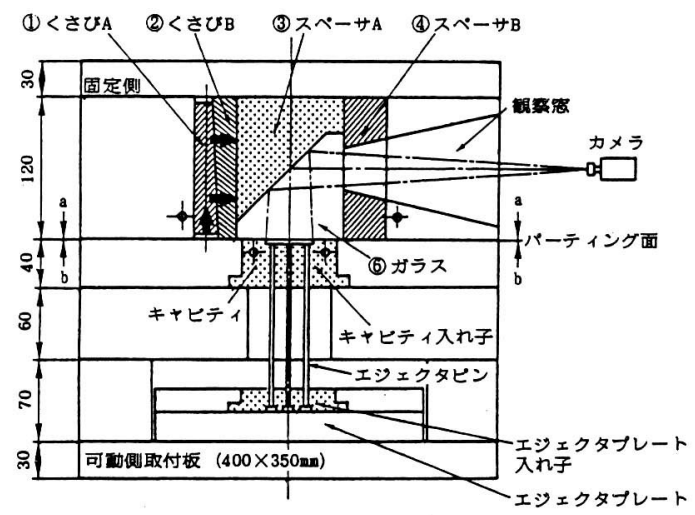

図7プリズムインサート金型の基本構造
オカメラによる可視化実験の様子を例示する. 同金 型は,すでに高度に多様化し,複雑となった現実の成 形現象解明に広く適用し得る可視化手法の確立を 指向したものである. すでに国内外10セット以上の 稼働実績を有しており,近年の画像計測技術の発達 により500〜 4,000frames/s (特殊な用途には20,000 frames/sまで)が,さらに拡大倍率として金型外から 70倍以上の撮影が可能となっている.これにより,ウ エルドライン ${ }^{30}$,フローマーク,シルバーストリーク ${ }^{311}$,ラ ンナーバランス ${ }^{32}$ などの不良現象解析が実施され，さ らにガスアシスト射出成形過程 ${ }^{33}$, ショートショット過 程 ${ }^{34}$ の可視化にも適用が拡げられている.

\section{(2)バックライト金型}

著者らは,上記プリズムインサート金型の発展研究 として,もう一つプリズムを対向させて組み付け，機能 的にPhoto Moldと同様の可視化金型を構成した ${ }^{35}$. この対向プリズムによるバックライト方式可視化金型 に基づき, $\phi 60 \mu \mathrm{m}, \phi 24 \mu \mathrm{m}$ のNiめっきガラス緎維 をマーカ纎維として用いることによって,繊維配向挙 動を直接観察することが可能になった(図9). 特に カメラ追跡装置との組み合わせにより,7層構造を形 成する繊維配向過程の解析に実績を上げた ${ }^{36)}$. 半 導体封止過程では,リードフレームを挟む2つのキャ ビティ充填パターンの可視化にも適用されている37.

\section{(3) 3 次元可視化金型}

成形現象は本質的に3次元流動現象に立脚して おり,CAEの今日的課題も3Dシミュレーションとなり つつある. プリズムインサート金型のキャビティ端部 にもう一つのプリズムを挿入し,リブ部,段差部, L字部

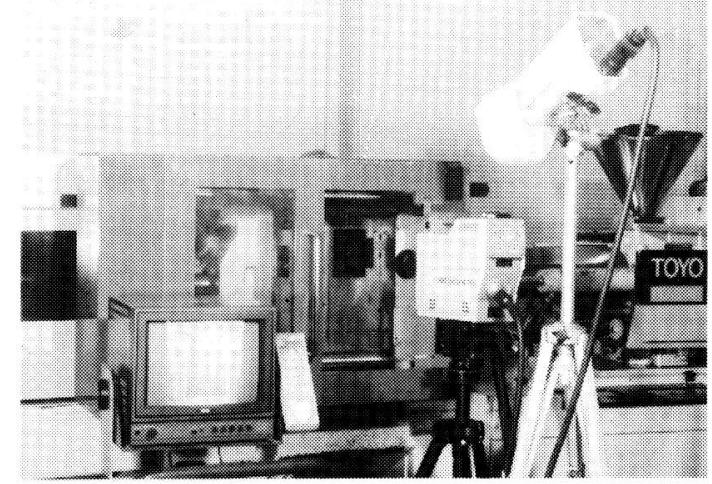

図8 プリズムインサート金型と高速ビデオ システム 
での充填挙動の 2 方向同時観察を可能とした ${ }^{38)} .2$ 台の高速ビデオシステムによる正面,側面画像を一 画面上に合成表示寸ることで,詳細な画像解析が可 能になっている.さらに同手法を拡張し,厚肉物・ガ スアシスト射出成形の可視化にも適用できる大型の 3次元可視化金型を開発した ${ }^{39}$. 同金型では,リブ・ ボス内部流れを同時に観察するため,リブ・ボス形状 の一部 (半分)をガラスブロックとし,さらに外側に側 面観察用ガラスブロックを組付けた構造に特徵があ る(図10)。縦少ブ,斜めリブ39),ボス ${ }^{40}$,段差キャビティ ${ }^{411}$ での充填現象, 高充填フィラー・高濃度ガラス纎維系 の樹脂流れ,さらにはガスアシスト射出成形のガス注

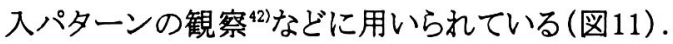

\section{（4）ランナー切替え装置}

ゲート着磁法のようにゲート通過樹脂をマーキン グするために,2色成形機と組合わせて,ゲート直前 で回転し,2つのランナーを瞬時に何回も切替える装 置を開発した (図12) ${ }^{43}$. これにより,分割面,側面観 察用のそれぞれの可視化金型と組合わせて,リブ,段 差,ボス部充填,ウェルドライン生成過程 (図13)につ いて,特にコア層流れを動的に可視化することに成 功している ${ }^{44)}$. 同手法は,単に動的な可視化解析にと どまらず,動的観察をした成形サンプルを取り出し任 意切断面を観察することで,内部流れの層状着色パ ターンを容易に観察できる. 両者を対比して解析す
ることで高度な害験解析が可能となることから,“究極 の可視化実験解析技術”として期待されるものであ る.

(5)拡大・追跡観察装置

成形品外観不良現象は,主に樹脂フロント部にお けるファウンテンフロー現象の乱れに起因している. それらの生成機構を解明するためには,フロントを拡 大観察することが最も直接的なアプローチ法と言え， 拡大・追跡観察手法の開発が求められていた.カメ ラを単軸移動ロボットに載せて追跡撮影する技術は 上記(2)で纎維配向の研究にて試行されたが,フロン トに注目した研究が横方向(板厚方向からのバック

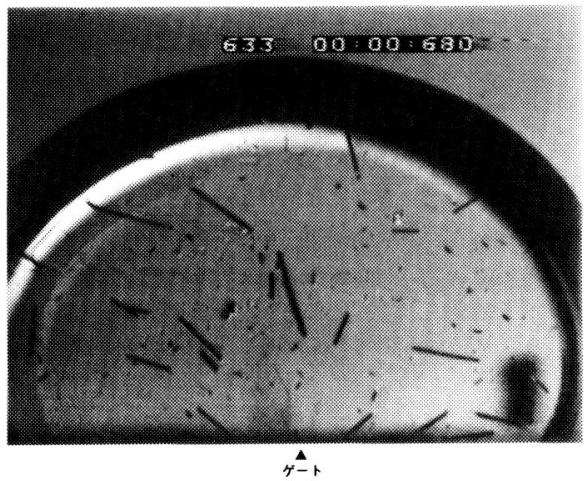

図9 ゲート近傍での織維配向過程（ガラス 緎稚径： $\phi 60 \mu \mathrm{m}$, 樹脂 : PS)

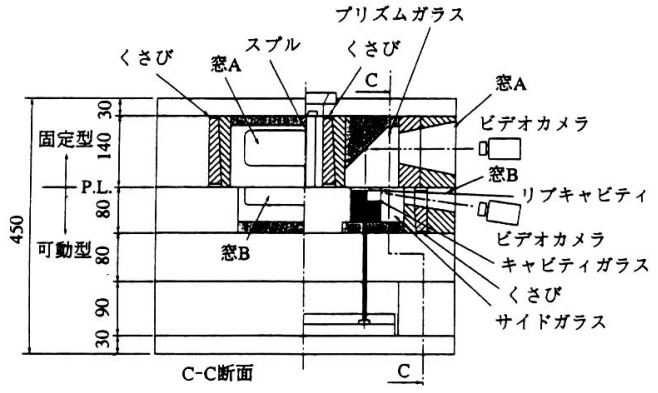

図10 大型 3 次元可視化金型（2 方向同時 可視化金型）の基本構造

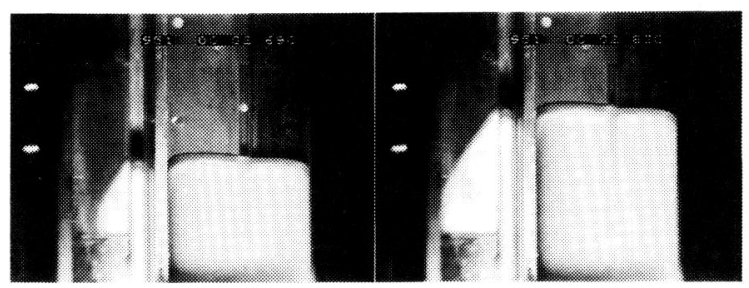

（a）リブ部充填挙動

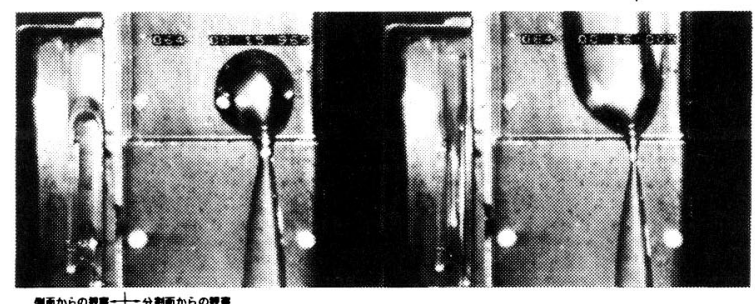

(b)ガスインジェクションにおける段差部ガス進入挙動

図11 2 方向同時可視化金型による観察画像の例 


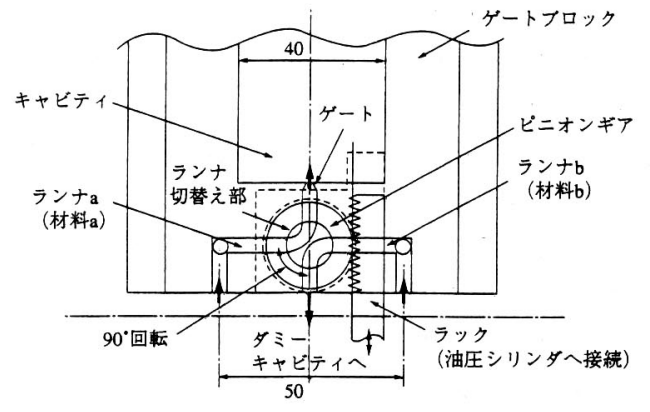

図12 ランナー切替え装置
ライト撮影) ${ }^{45}$, 手前方向 (フロント部前方からの合焦 点撮影)の拡大観察実験として行われた.さらに,ラ インセンサーのインプロセス計測により,対象物 (例 えばフローフロント先端部)を横方向観察画像の視 野内に常時捉える自動追跡システムの開発を行い, 最大 $200 \mathrm{~mm} / \mathrm{s}$ までの拡大追跡速度を実現してい $ろ^{46)}$. 観察対象は,繊維配向過程,フローフロントの対 称・非対称ファウンテンフロー過程,シルバーストリー ク生成過程等,多㞳にわたる.

\section{4.おわりに}

可視化技術はここ10年で大きな進歩を遂げ,プラ スチック成形加工の多くの分野で一般的な実験解 析手法として広く市民権を得るに至っている スチック成形加工関連の大きな国際学会年次大会 (PPS Annual Meeting, SPE ANTEC)では'96,'97, '98と近年毎年のように可視化セッションが設けられ るようになり,可視化研究は今や国際的な潮流となっ ている.

可視化技術はその利用形態から,シミュレーション 検証用の基礎データ収集を目的にするものと,未知 の成形現象を発見的手法により解明することを目的 にするものと,大きく2つに分けられる. 前者は, 基本 的なモデル実験を課題とするため, 可視化技術に対 する課題は物理状態を読み出す計測手法 (例えば, 速度分布, 忘力・複屈折分布,圧力分布, 温度分布な どの計測法)にある.すなわち,これらをいかにして

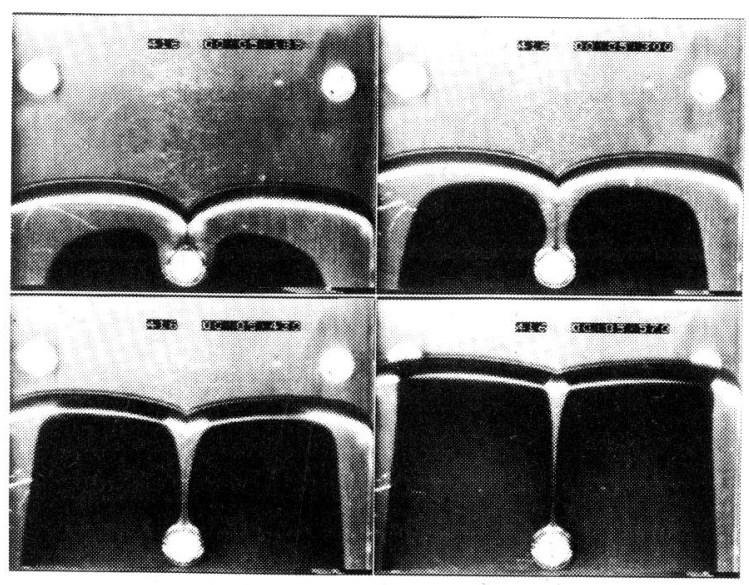

図13 ランナー切替え装置によるウェルドライン 形成過程の観察

正確に計測できるかが可視化技術に対する要求課 題となる.一方,後者では，現実の不良現象を可視化 金型内でいかにして再現し,ありのままの現象を定性 的・定量的に捉えるかが課題になる.一般には,材 料特性のばらつきや,金型の表面性状,微妙な滞留 現象や不安定現象など,すぐにはシミュレーションで きないような現象が対象となっている.この場合に は,いかにして実際の加エプロセスを実機上で可視 化するかが課題となり,可視化技術にも妥協の許さ れない難度が要求される.

可視化技術は温度・圧力計測技術とともに実験 解析分野の発展を支え, 一方の予測技術としての CAE分野と両輪をなしつつ,プラスチック成形加工を リードする役割を担おうとしている. 前者の利用形態 として,CAE高精度化への要望とともに，今後CAEに 導入されるべき実成形現象のモデル化を実現する ことが求められる。そのため、後者の可視化技術に 対する要望,すなわち末知の成形現象の解明が,今 後ますます大きくなるものと予想される.

本稿が,金型内成形現象の可視化実験解析法の 普及に対して一助となれば幸いである。

\section{参考文献}

1)横井秀俊:成形加工, Vol.6, No.2, pp.157 (1994).

2)Spencer,R.S., and Gilmore,G.D.: J.Colloid,Sci., No6, pp.118 (1951).

3)Gilmore,G.D., and Spencer,R.S.: Mod.Plastics, No. 
28, pp.117 (1951).

4)White,J.L., and Dee,H.B.: Polym.Eng.Sci., Vol.14, No.3, pp.212 (1974).

5)White,J.L., and Lee,B.L.: Polym.Eng.Sci., Vol.15, No.7, pp.481 (1975).

6)Oda,K., White,J.L., and Clark,E.: Polym.Eng.Sci, Vol.16, No.8, pp.585 (1976).

7)Han,C.D., and Villamizar,C.A.: Polym.Eng.Sci., Vol. 18, No.9, pp.687 (1978).

8)Han,C.D., and Yoo,H.J.: Polym.Eng.Sci., Vol.21, No.9, pp.518 (1981).

9)Han,C.D., and Villamizar,C.A.: Polym.Eng.Sci., Vol. 18, No.3, pp.173 (1978).

10)黒崎晏夫,佐藤 您, 石井浩一郎: 日本機械学会論文 集(C編)，56-522C, pp.504 (1990).

11)黒崎晏夫,龍腰健太郎,佐藤 勲: 成形加工, Vol.2, No.6, pp.505 (1990).

12)Kamal,M.R., and Kenig,S.: Polym.Eng.Sci., Vol.12, No.4, pp.302 (1972).

13)高橋秀郎,松岡孝明:高分子学会レオロジー研究会講 演要旨集, pp.14 (1978).

14)Menges,G., and Leibfried,D.: Plastverarbeiten, No. 21, pp.951 (1970).

15)Lanvers,A.P.: Doctoral dissertation, IKV (1993).

16)Yang,S.Y., Huang, F.Z., and Liau,W.N.: Polym.Eng. Sci., Vol.36, No.23, pp.2824 (1996).

17)横井秀俊,稲垣幸秀,中西博之:成形加工'90, pp.143 (1990).

18)Coyle,D.J., Blake,J.W., and Macosko,C.W.: AIChE Journal, Vol.33, No.7, pp.1168 (1987).

19)Bagley,E.B., and Birks,A.M.: J.Appl.Phys., Vol.31, No.3, pp.556 (1960).

20)Schmidt,L.R.: Polym.Eng.Sci., Vol.14, No.11, pp. 797 (1974).

21)Vos,E., Meijer,H.E.H., and Peters, G.W.M.: Int'l Polymer Processing, No.6, pp.42 (1991).

22)横井秀俊,鎌田重人:生産研究, Vol.40, No.10, pp. 532 (1988).

23)横井秀俊,伊藤義一:成形加工'94, pp.45 (1994).

24)今出政明,宮内秀和,岡田三郎,横井秀俊：成形加工 シンポジア'96, pp.257 (1996).

25)太田 隆,横井秀俊:成形加エシンポジア'98, pp.71 (1998).

26)佐藤正博, 中村俊康, 横井秀俊: 成形加エシンポジア
'99, pp.191 (1999).

27)宮内秀和,今出政明,岡田三郎,横井秀俊,增田範通:

成形加エシンポジア’95, pp.49 (1995).

28)横井秀俊,林 高樹,平岡弘之:生産研究, Vol.39, No.

7, pp.306 (1987).

29)横井秀俊,村田泰彦,坂本一郎:成形加工, Vol.6, No. 5 , pp.349 (1994).

30)横井秀俊,村田泰彦,岡 克典,渡辺広三:成形加工, Vol.9, No.4, pp.290 (1997).

31)村田泰彦,横井秀俊,長谷元弘,永見 哲,渡辺広三: 生産研究, Vol.45, No.6, pp.421 (1993).

32)横井秀俊,村田泰彦,長谷元弘:成形加工, Vol.9, No. 7, pp.557 (1997).

33)横井秀俊,大竹智文:成形加エシンポジア'98, pp.59 (1998).

34)村田泰彦,横井秀俊,宇高 靖:成形加工, Vol.6, No. 10, pp.703 (1994).

35)横井秀俊,村田泰彦,西 芳夫, 関 武邦:成形加工, Vol.7, No.9, pp.600 (1995).

36)村田泰彦,横井秀俊,長谷元弘,原田浩次:成形加工, Vol.7, No.10, pp.663 (1995).

37)横井秀俊,村田泰彦,山口龍善:生産研究, Vol.48, No.4, pp.266 (1996).

38)横井秀俊,梅山 浩,宇高 靖,村田泰彦:成形加工, Vol.9, No.3, pp.232 (1997).

39)横井秀俊,櫛田茂美,松坂 茂,松田 元:生産研究, Vol.49, No.9, pp.434 (1997).

40)松田 元,横井秀俊:生産研究, Vol.51, No.3, pp. 125 (1999).

41)松田 元,横井秀俊:生産研究, Vol.51, No.9, pp. 682 (1999).

42)Yokoi,H., and Otake,T.: Abstracts for the PPS-14, pp.77 (1998).

43)横井秀俊,金藤芳典:成形加エシンポジア’96, pp.131 (1996).

44)Yokoi,H., Kanetoh,Y., and Murata,Y.: Polymer Process Engineering 99, pp.109 (1999), IOM Communications.

45)横井秀俊,増田範通: 成形加工'95, pp.145 (1995).

46)光畑晴彦,横井秀俊:成形加エシンポジア'98, pp.351 (1998).

47)横井秀俊:成形加I, Vol.11, No.4, pp.332 (1999).

(1999 年 9 月 30 日受付) 